\title{
STATUS PERLINDUNGAN BURUNG LIAR YANG DIPERDAGANGKAN DI KABUPATEN KUBU RAYA
}

\author{
(The Protection Status Of Traded Wild Bird In Kubu Raya Regency)
}

\author{
Tri Mulyana, H. Erianto, Siti Masitoh Kartikawati \\ Fakultas Kehutanan Universitas Tanjungpura Jalan Daya Nasional Pontianak 78124 \\ E-mail : triiimulyana@gmail.com
}

\begin{abstract}
Birds are aves class that have ecological, economic and socio-cultural functions. For the community, birds are used as pets and trading. The trading wild birds in Kubu Raya Regency for the last 3 years has greatly increased, along with the rise of the song birds contest this has made birds become popular pet among the people in Kubu Raya Regency. This study aims to determine the protection status of traded bird species in Kubu Raya Regency. This research used survey and observation methods, the technique of respondent data collecting usedsnowball sampling, which is to determine the key of respondents who are people had extensive knowledge of bird trading activities in Kubu Raya Regency. The results of the study there are 11 respondents that is 3 hunter categories, 1 collecting category and 7 bird shops / traders. The results obtainedthere are 572 traded birds consisting of 39 species belonging to 21families. The originlocation of the traded birds came from different regions that is Kubu Raya, Jungkat, Sambas, Tayan, Pahuman, Ketapang, Sintang, Badau, and Putussibau. There are 10 protected birds species including 4 species according to Indonesian Law, 1 bird species in the CITES Appendix II category (Convention on International Trade of Endangered Species of Wild Fauna and Flora) and 8 bird species listed in the IUCN Red List category (International Union For the Conservation of Nature and Natural Resources).
\end{abstract}

Keyword: Bird Species, Trading Of Bird, Protection Of Bird, Kubu Raya.

\section{PENDAHULUAN}

Indonesia merupakan negara yang kaya akan keanekaragaman jenis fauna, namun pengelolaan sumber daya alam ini belum dilakukan secara optimal, sehingga banyak jenis burung yang terancam punah. Penyebab utama yang mengancam kepunahan adalah hilang atau rusaknya habitat dan perburuan untuk perdagangan (Metz, 2005). Perdagangan satwa liar menjadi ancaman yang serius bagi kelangsungan hidup satwa di alam karena sekitar 95\% satwa yang diperdagangkan berasal dari tangkapan alam dan sisanya hasil penangkaran (Profauna, 2009).
Adanya permintaan burung oleh sebagian masyarakat menjadi suatu peluang pasar bagi pedagang dan penangkap burung untuk mendapatkan keuntungan secara ekonomi. Dalam memenuhi kebutuhan permintaan burung maka pedagang selalu berupaya menyediakan burung untuk pembeli. Berbagai upaya ditempuh untuk mendapatkan pasokan burung sehingga pedagang dan penangkap burung sering tidak memperhatikan ancaman terhadap kelestarian burung di alam (Haryoko, 2010). Banyak terjadi penangkapan burung secara liar yang menyebabkan populasi burung di alam jadi berkurang 
karena ditangkap secara berlebihan. Tanpa disadari sebagian dari burung yang ditangkap tersebut ada beberapa burung yang berstatus dilindungi, yang artinya burung tersebut tidak boleh sembarangan ditangkap apalagi sampai dijual (Saifuddin, 2013)

Seiring meningkatnya kontes burung kicau yang diselenggarakan di Kabupaten Kubu Raya, hal ini menjadikan burung menjadi hewan peliharaan yang sangat diminati dan popular di kalangan masyarakat. Burung kicau memberikan pendapatan terhadap masyarakat karena selain menjual burung, pedagang burung juga menjual makanan burung, sangkar burung, peralatan pemeliharaan burung, peralatan penangkapan burung serta aksesori burung lainnya. Pengetahuan mengenai burung yang dilindungi di kalangan masyarakat masih kurang, Hal ini menjadi salah satu faktor yang menjadi ancaman terhadap keanekaragaman burung baik yang dilindungi maupun yang tidak dilindungi di alam. Eksploitasi burung yang berlebihan, perburuan dan penangkapan serta perdagangan burung secara langsung pada habitat alaminya akan berdampak mengurangi populasinya di alam, kegiatan-kegiatan tersebut apabila tidak dikontrol dengan sebaik-baiknya akan dapat menyebabkan menurunnya keanekaragaman jenis-jenis burung tersebut bahkan dapat menimbulkan resiko yang lebih buruk lagi yaitu punahnya jenis-jenis burung di habitat alaminya. Tujuan penelitian ini adalah untuk mengetahui status perlindungan burung liar yang diperdagangkan di Kabupaten Kubu Raya. Manfaat penelitian ini memberikan informasi mengenai status perlindungan jenis-jenis burung yang diperdagangkan di Kabupaten Kubu Raya.

\section{METODE PENELITIAN}

Penelitian ini dilaksanakan pada tanggal 8 Maret sampai dengan tanggal 28 Maret 2019 di Kabupaten Kubu Raya. Alat dan bahan yang digunakan untuk pengambilan data dilapangan terdiri dari : Alat rekaman, Kamera, Buku pedoman Phillipps' Field Guide To The Birds Of Borneo Sabah, Sarawak, Brunei and Kalimantan (2014), John Mackinnon, Karen Phillipps, Bas Van Ballen'Burungburung di Sumatera, Jawa, Bali, dan Kalimantan (2010). Objek dalam pengambilan data adalah masyarakat yang terlibat langsung dalam kegiatan perdagangan burung yaitu pemburu, penampung dan pedagang burung di Kabupaten Kubu Raya serta burung yang diperjualbelikan. Pengambilan data di lapangan penelitian ini bersifat deskriptif kualitatif dengan menggunakan teknik snowball sampling (Bernard, 2002), dengan cara menentukan responden kunci untuk kemudian menentukan responden lain yang juga mengetahui informasi terkait dari responden sebelumnya. Maksud dari responden kunci adalah orang yang memiliki pengetahuan luas mengenai kegiatan perdagangan burung. Responden tersebut ditujukan langsung kepada pedagang burung yang ada di Kabupaten Kubu Raya yang dianggap dapat membantu melengkapi data. Data primer yang digali adalah jenis burung, asal burung, jumlah burung, harga burung dan latar belakang pembeli burung. Data sekunder berupa kondisi umum lokasi 
pengambilan data yang diperoleh dari berbagai sumber terkait baik dari instansi, badan atau lembaga dan literatur yang dianggap perlu seperti data mengenai lokasi toko burung berada.

Analisa data yang dilakukan untuk menjelaskan data yang diperoleh dari lapangan dilakukan 2 tahap yaitu :

Metode Deskriptif

Metode Deskriptif merupakan metode dalam meneliti status sekelompok manusia, suatu objek, suatu kondisi, suatu sistem pemikiran ataupun suatu kelas peristiwa pada masa sekarang. Tujuan dari penelitian deskriptif ini adalah untuk membuat deskripsi, faktual dan akurat mengenai fakta-fakta, sifat-sifat serta hubungan antar fenomena yang diselidiki terhadap pemanfaatan jenis burung (Nazir, 1998).

Pendekatan kualitatif dalam penelitian ini dimaksudkan untuk menghasilkan data deskriptif berupa ucapan atau tulisan dan perilaku yang dapat diamati dari subjek itu sendiri data tersebut kemudian dianalisis (Maleong, 2010).

\section{Status Perlindungan}

Status Perlindungan mengacu pada :

a. Undang Undang Nomor 5 Tahun 1990 Tentang Konservasi

Sumberdaya Alam Hayati Dan Ekosistemnya.

b. Peraturan Menteri Lingkungan Hidup Dan Kehutanan Republik Indonesia Nomor

P.106/MENLHK/SETJEN/KUM.1/1

2/2018 Tentang Perubahan Kedua Atas Peraturan Menteri Lingkungan Hidup Dan Kehutanan. c. Status keterancaman menurut IUCN(International Union For the Conservation of Nature and Natural Resources)/IU mengacu kepada Redlist IUCN yang meliputi :

a. $\mathrm{EX}=$ Extinct (punah).

b. $\mathrm{EW}=$ Extinct in the Wild (punah di alam).

c. $\mathrm{CR}=$ Critically Endangered (sangat terancam punah).

d. $\mathrm{EN}=$ Endangered (terancam punah).

e. $\mathrm{VU}=$ Vulnerable (terancam).

f. NT = Near Threatened (mendekati terancam).

g. $\mathrm{NE}=$ Not Evaluated (belum di evaluasi).

h. $\mathrm{DD}=$ DataDeficient (data kurang), sementara untuk kategori

i. $\mathrm{LC}=$ (Least Concern) dikeluarkan (tidak dicantumkan dalam daftar).

d. Status perlindungan berdasarkan Peraturan Perdagangan Internasional menurut CITES/CI (Convention on Iternational Trade of Endangered Species of Wild Fauna and Flora) mengelompokkan kategori-kategori jenis dalam 3 Appendix (Lampiran) yaitu :

a. Lampiran Appendix I (semua jenis yang terancam punah dan berdampak apabila diperdagangkan. Perdagangan hanya diijinkan hanya dalam kondisi tertentu misalnya untuk riset ilmiah).

b. Lampiran Appendix II (jenis yang statusnya belum terancam tetapi 
akan terancam punah apabila dieksploitasi berlebihan).

c. Lampiran Appendix III (seluruh jenis yang juga dimasukan dalam peraturan di dalam perdagangan dan negara lain berupaya mengontrol dalam perdagangan tersebut agar terhindar dari eksploitasi yang tidak berkelanjutan)

\section{HASIL DAN PEMBAHASAN}

Tabel 1. Jenis Jenis Burung Yang Diperdagangkan Di Kabupaten Kubu Raya.

\begin{tabular}{|c|c|c|c|c|c|c|c|}
\hline \multirow{2}{*}{ Famili } & \multirow{2}{*}{ No } & \multicolumn{2}{|c|}{ Jenis } & \multirow{2}{*}{$\begin{array}{c}\text { Jumlah } \\
\text { Individu }\end{array}$} & \multirow{2}{*}{$\%$} & \multicolumn{2}{|c|}{ Keterangan } \\
\hline & & Nama Latin & Nama Lokal & & & Alam & Ternak \\
\hline Aegithinidae & 1. & Aegithina tiphia & Sirtu & 1 & 0,17 & $\sqrt{ }$ & \\
\hline Cacatuidae & 2. & Nymphicus hollandicus & Parkit australi & 6 & 1,05 & & $\sqrt{ }$ \\
\hline \multirow[t]{2}{*}{ Campephagidae } & 3. & Hemipus hirundinaceus & Keke' babi & 1 & 0,17 & $\sqrt{ }$ & \\
\hline & 4. & Pericrocotus flammeus & Mantenan jawa & 4 & 0,7 & $\sqrt{ }$ & \\
\hline Chloropseidae & 5. & Chloropsis sonnerati & Cucak hijau & 8 & 1,4 & $\sqrt{ }$ & \\
\hline \multirow[t]{5}{*}{ Columbidae } & 6. & Columba domestica & Merpati & 14 & 2,45 & & $\sqrt{ }$ \\
\hline & 7. & Geopelia striata & Perkutut & 42 & 7,34 & & $\sqrt{ }$ \\
\hline & 8. & Streptopelia chinensis & Tekukur & 22 & 3,85 & $\sqrt{ }$ & \\
\hline & 9. & Streptopelia dusumieri & Putar & 6 & 1,05 & $\sqrt{ }$ & \\
\hline & 10. & Treron vernans & Punai & 2 & 0,35 & $\sqrt{ }$ & \\
\hline Corvidae & 11. & Platylophus galericulatus & Celilin & 2 & 0,35 & $\sqrt{ }$ & \\
\hline Dicaeidae & 12. & Dicaeum trigonostigma & Api api & 15 & 2,62 & $\sqrt{ }$ & \\
\hline Fringillidae & 13. & Serinus canaria & Kenari & 9 & 1,57 & & $\sqrt{ }$ \\
\hline Irenidae & 14. & Irena puella & Cucak biru & 1 & 0,17 & $\sqrt{ }$ & \\
\hline Laniidae & 15. & Lanius schach bentet & Pentet & 37 & 6,47 & $\sqrt{ }$ & \\
\hline Muscicapidae & 16. & Cyornis rufigastra & Teledekan & 3 & 0,52 & $\sqrt{ }$ & \\
\hline \multirow[t]{3}{*}{ Nectariniidae } & 17. & Chalcoparia singalensis & Kolibri & 8 & 1,4 & $\sqrt{ }$ & \\
\hline & 18. & Nectarinia calostetha & King konen & 4 & 0,7 & $\sqrt{ }$ & \\
\hline & 19. & Nectarinia sperata & Konen & 15 & 2,62 & $\sqrt{ }$ & \\
\hline Picidae & 20. & Dinopium javanense & Pelatuk bawang & 2 & 0,35 & $\sqrt{ }$ & \\
\hline \multirow[t]{4}{*}{ Psittacidae } & 21. & Agapornis lilianae & Love bird & 50 & 8,74 & & $\sqrt{ }$ \\
\hline & 22. & Agapornis personata & Love bird & 25 & 4,37 & & $\sqrt{ }$ \\
\hline & 23. & Loriculus galgulus & Serindit & 3 & 0,52 & $\sqrt{ }$ & \\
\hline & 24. & Melopsittacus undulates & Parkit & 6 & 1,05 & & $\sqrt{ }$ \\
\hline \multirow[t]{4}{*}{ Pycnonotidae } & 25. & Pycnonotus aurigaster & Kutilang & 35 & 6,12 & $\sqrt{ }$ & \\
\hline & 26. & Pycnonotus brunneus & Cucak jenggot & 1 & 0,17 & $\sqrt{ }$ & \\
\hline & 27. & Pycnonotus eutilotus & Merbak gunung & 3 & 0,52 & $\sqrt{ }$ & \\
\hline & 28. & Pycnonotus goiavier & Merbah cerucuk & 5 & 0,87 & $\sqrt{ }$ & \\
\hline Rhipiduridae & 29. & Rhipidura javanica & Sikatan & 2 & 0,35 & $\sqrt{ }$ & \\
\hline \multirow[t]{2}{*}{ Sturnidae } & 30. & Acridotheres javanicus & Jalak & 20 & 3,5 & $\sqrt{ }$ & \\
\hline & 31. & Sturnus contra & Jalak suren & 1 & 0,17 & & $\sqrt{ }$ \\
\hline \multirow[t]{2}{*}{ Sylviidae } & 32. & Orthotomus ruficeps & Perenjak & 10 & 1,75 & $\sqrt{ }$ & \\
\hline & 33. & Prinia flaviventris & Cibli' sawah & 14 & 2,45 & $\sqrt{ }$ & \\
\hline \multirow[t]{2}{*}{ Timaliidae } & 34. & Malacopteron magnum & Perenjak batu & 3 & 0,52 & $\sqrt{ }$ & \\
\hline & 35. & Yuhina zantholeuca & Cicak keladi & 5 & 0,87 & $\sqrt{ }$ & \\
\hline \multirow[t]{3}{*}{ Turdidae } & 36. & Copsychus malabaricus & Murai batu & 37 & 6,47 & $\sqrt{ }$ & \\
\hline & 37. & Copshycus saularis musicus & Kacer & 74 & 12,9 & $\sqrt{ }$ & \\
\hline & 38. & Zoothera interpres & Anis kembang & 1 & 0,17 & $\sqrt{ }$ & \\
\hline Zosteropidae & 39. & Zosterops palpebrosus & Pleci & 75 & 13,1 & $\sqrt{ }$ & \\
\hline Jumlah Individu & & & & 572 & & & \\
\hline Jumlah Jenis & & & & 39 & & & \\
\hline Jumlah Famili & & & & 21 & & & \\
\hline
\end{tabular}


Tabel 1 merupakan jenis-jenis burung yang diperjualbelikan di Kabupaten Kubu Raya. Hasil survey dan observasi di lapangan terdapat 7 toko burung, toko-toko tersebut berada di Kecamatan Sungai Raya dan Kecamatan Sungai Ambawang. Burungburung yang diperjualbelikan berhasil diidentifikasi dengan jumlah 572 burung dari 39 jenis yang tergolong kedalam 21 suku famili. Sebagian besar burung tersebut merupakan burung liar hasil tangkapan alam terkecuali untuk jenis Love bird (Agapornis lilianae, Agapornis personata), Merpati (Columba domestica), Perkutut (Geopelia striata), Parkit (Melopsittacus undulates), Parkit australi (Nymphicus hollandicus), Kenari (Serinus canaria), dan Jalak suren (Sturnus contra) yang merupakan burung ternak.

Burung-burung yang diperdagangkan memiliki harga yang bervariasi tergantung dengan kelebihan jenis burung tersebut, salah satunya adalah keindahan suara burung. Menurut Juhardiansyah et al, (2019) variasi dan kisaran harga jenis burung ditentukan oleh pedagang berdasarkan karakteristik burung yang bersangkutan, harga dipengaruhi oleh jenis burung dilihat dari keindahan suaranya, keindahan warna bulunya, dan jenis kelaminnya. Karakteristik masingmasing jenis burung dapat memberikan kepuasan tersendiri bagi masyarakat (konsumen) dalam memeliharanya, baik para konsumen pecinta burung kicau yang memanfaatkan burung sebagai ajang kontes maupun para konsumen penghobi burung yang memanfaatkan burung untuk dijadikan burung hias di rumah.

Berdasarkan informasi yang didapat dari pedagang, burung-burung yang diperjualbelikan berasal dari beberapa tempat diantaranya Kubu Raya, Jungkat, Sambas, Tayan, Pahuman, Ketapang, Sintang, Badau, dan Putussibau. Burung-burung yang diperdagangkan masing-masing jenis memiliki tingkat penjualan, ada beberapa jenis yang tingkat penjualannya tinggi adapula jenis burung tingkat penjualannya rendah tergantung dari karakteristik dan yang dimiliki jenis burung dan pemanfaatan jenis burung tersebut (Gambar.1).

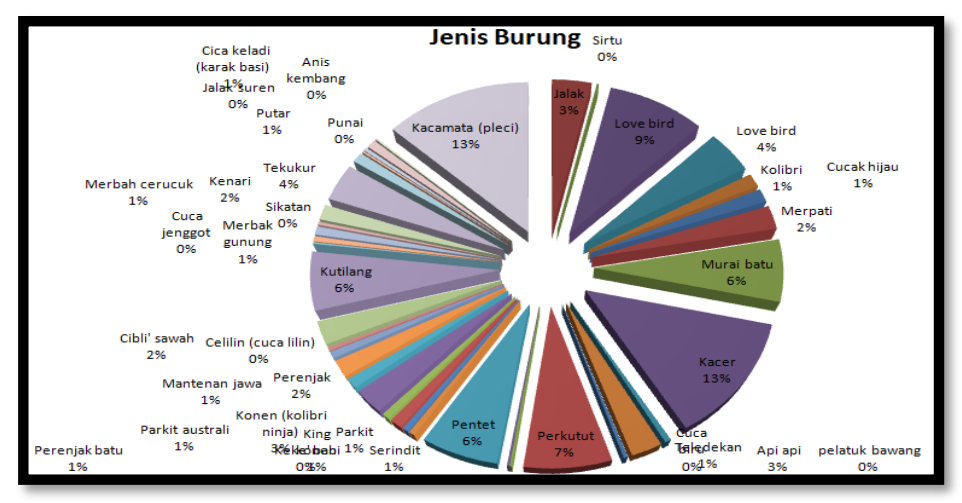

Gambar 1. Persentase Burung yang diperdagangkan berdasarkan jenis 
Gambar 1. Menunjukkan jenis burung yang paling banyak diperdagangkan adalah jenis Pleci (Zosterops palpebrosus) 13,1 \%, disusul Kacer (Copshycus saularis musicus)12,9\%, Love bird (Agapornis lilianae) 8,74 \%, Perkutut (Geopelia striata) 7,34 \% dan Murai batu (Copshycus malabaricus) 6,47 \%. Menurut Juhardiansyah et al (2019) bahwa jenis burung yang paling banyak diperdagangkan diantaranya adalah jenis Kacer (Copshycus saularis musicus) dan Murai batu (Copshycus malabaricus) hal ini dikarenakan kedua jenis burung tersebut memiliki keindahan suara dan jenis ini merupakan burung yang sangat diminati dan popular dikalangan masyarakat untuk dimanfaatkan sebagai burung kontes, sehingga kedua jenis burung ini paling banyak diperdagangkan, hal ini mengungkapkan kenyataan bahwa kedua jenis ini telah menjadi komoditas ekonomi dengan permintaan pasar yang kuat.

Jenis burung yang paling sedikit diperdagangkan diantaranya Sirtu (Aegithina tiphia) 0,17\%, Keke' babi (Hemipus hirundinaceus) 0,17\%, Cuca biru (Irena puella) 0,17\%, Cuca jenggot (Pycnonotus brunneus) 0,17\%, Jalak suren (Sturnus contra) 0,17\%, dan Anis kembang (Zoothera interpres) $0,17 \%$. Hasil wawancara kepada pemburu menjelaskan bahwa jenis-jenis burung tersebut dulu nya sangat mudah ditemukan namun saat ini sangat sulit ditemukan di alam, sehingga mempengaruhi ketersediaan burung dipasar. Dalam Juhardiansyah et al (2019) menyatakan tingginya aktivitas perburuan burung liar merupakan masalah utama yang dapat mempengaruhi keterancaman keberadaan jenis maupun populasi burung di alam.

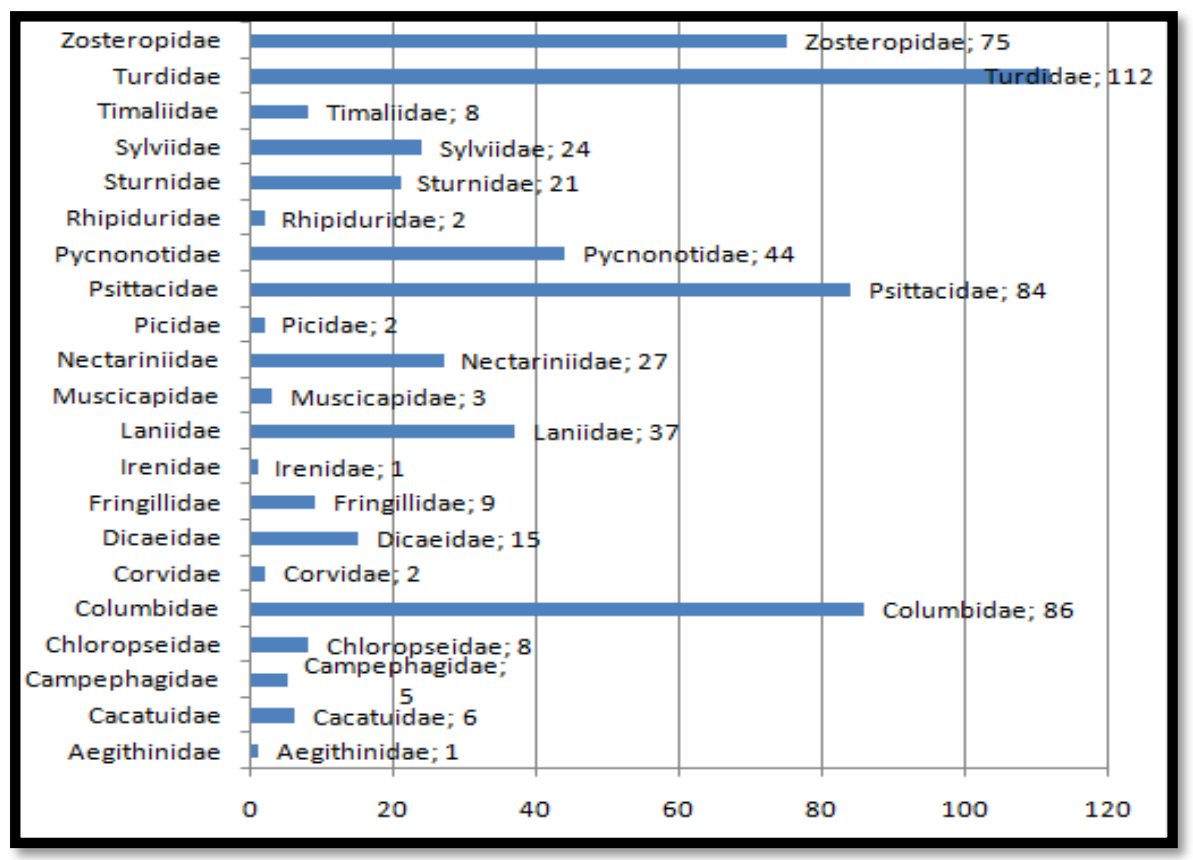

Gambar 2. Diagram batang burung yang diperdagangkan berdasarkan famili 
Gambar 2. menunjukkan famili Turdidae merupakan jumlah burung terbanyak yang diperdagangkan yaitu (112 ekor), diikuti Columbidae (86 ekor), Psittacidae (84 ekor), dan Zosteropidae (75 ekor). Dalam penelitian Haryoko (2010) mengenai burung yang diperdagangkan di Jawa Barat dalam hasil penelitiannya bahwa jenis burung yang paling banyak diperjualbelikan diantaranya adalah jenis burung yang berasal dari suku famili Turdidae dan Zosteropidae. Serta hasil wawancara kepada pedagang burung di Kabupaten Kubu Raya menjelaskan bahwa burung yang diminati masyarakat adalah diantaranya merupakan jenis burung yang memiliki keindahan suara untuk dimanfaatkan sebagai burung kontes yang sebagian besar burug-burung tersebut berasal dari famili Turdidae, Psittacidae dan Zosteropidae seperti Murai batu, Kacer, Love bird dan Serindit, selain itu jenis burung yang paling banyak diperdagangkan terdapat juga dari suku (famili) Columbidae, jenis burungnya yaitu Merpati, Perkutut, Tekukur, Putar, dan Punai. Burung-burung yang tergolong ke dalam 1 famili ini merupakan jenis burung yang digemari masyarakat para penghobi burung untuk dimanfaatkan sebagai burung hias, salah satu faktor yang menarik dari jenis-jenis burung ini salah satunya adalah harga yang rendah.

Untuk jenis Punai (Treron vernans) sebagian masyarakat memanfaatkan jenis burung ini untuk dijadikan bahan makanan. Menurut Sawitri et al (2010)
Punai termasuk salah satu jenis burung dari suku Columbidae yang banyak diburu di Indonesia untuk kepentingan konsumsi bagi beberapa masyarakat dan burung punai menjadi pemenuhan kebutuhan protein hewani karena mudah di dapat dan harganya murah, sehingga burung dari famili Columbidae ini termasuk dalam jenis burung dengan tingkat penjualan yang tinggi.

Jenis burung yang paling sedikit diperdagangkan berasal dari famili Aegithinidae yaitu jenis Sirtu (Aegithina tiphia) dan Irenidae yaitu Cuca biru (Irena puella) dikarenakan jenis burung ini sulit ditemukan di alam serta harga burung yang rendah. Menurut MacKinnon et al (2010) jenis ini merupakan jenis penghuni taman, hutan mangrove, hutan terbuka dan hutan sekunder. Hal ini juga menjadi salah satu faktor persediaan burung terbatas karena sebagian besar pemburu jarang berburu pada hutan mangrove dan area taman sehingga mempengaruhi ketersediaan jenis burung ini untuk diperdagangkan. 
JURNAL HUTAN LESTARI (2019)

Vol. 7 (3) : 1412 - 1423

\section{Status Perlindungan Burung}

Tabel 2.Status Perlindungan Burung Yang Diperadagangkan Di Kabupaten Kubu Raya.

\begin{tabular}{|c|c|c|c|c|c|}
\hline \multirow{2}{*}{ No } & \multirow{2}{*}{ Nama Ilmiah } & \multirow{2}{*}{ Nama Lokal } & \multicolumn{3}{|c|}{ Status Konservasi } \\
\hline & & & ${ }^{1}$ P.106-2018 & ${ }^{2}$ IUCN-2019 & ${ }^{3}$ CITES \\
\hline 1. & Acridotheres javanicus & Jalak & & $\mathbf{V U}$ & \\
\hline 2. & Aegithina tiphia & Sirtu & & LC & \\
\hline 3. & Agapornis lillianae & Love bird & & NT & \\
\hline 4. & Agapornis personata & Love bird & & LC & \\
\hline 5. & Anthreptes singalensis & Kolibri & & LC & \\
\hline 6. & Chloropsis sonnerati & Cucak hijau & $\mathbf{A B}$ & VU & \\
\hline 7. & Columba domestica & Merpati & & LC & \\
\hline 8. & Copshycus malabaricus & Murai batu & & LC & \\
\hline 9. & Copshycus saularis mиsicus & Kacer & & LC & \\
\hline 10. & Cyornis rufigastra & Teledekan & & LC & \\
\hline 11. & Dicaeum trigonostigma & Api api & & LC & \\
\hline 12. & Dinopium javanense & Pelatuk bawang & & $\mathbf{L C}$ & \\
\hline 13. & Geopelia striata & Perkutut & & LC & \\
\hline 14. & Hemipus hirundinaceus & Keke' babi & & LC & \\
\hline 15. & Irena puella & Cuca biru & & LC & \\
\hline 16. & Lanius schach bentet & Pentet & & LC & \\
\hline 17. & Loriculus galgulus & Serindit & $\mathbf{A B}$ & LC & II \\
\hline 18. & Malacopteron magnum & Perenjak batu & & NT & \\
\hline 19. & Melopsittacus undulates & Parkit & & LC & \\
\hline 21. & Nectarinia sperata & Konen & & LC & \\
\hline 22. & Nymphicus hollandicus & Parkit australi & & LC & \\
\hline 23. & Orthotomus ruficeps & Perenjak & & LC & \\
\hline 24. & Pericrocotus flammeus & Mantenan jawa & & LC & \\
\hline 25. & Platylophus galericulatus & Cuca lilin & AB & NT & \\
\hline 26. & Prinia flaviventris & Cibli' sawah & & LC & \\
\hline 27. & Pycnonotus aurigaster & Kutilang & & LC & \\
\hline 28. & Pycnonotus brunneus & Cuca jenggot & & LC & \\
\hline 29. & Pycnonotus eutilotus & Merbak gunung & & NT & \\
\hline 30. & Pycnonotus goiavier & Merbah cerucuk & & LC & \\
\hline 31. & Rhipidura javanica & Sikatan & $\mathbf{A B}$ & LC & \\
\hline 32. & Serinus canaria & Kenari & & LC & \\
\hline 33. & Streptopelia chinensis & Tekukur & & LC & \\
\hline 34. & Streptopelia dusumieri & Putar & & VU & \\
\hline 35. & Sturnus contra & Jalak suren & & LC & \\
\hline 36. & Treron vernans & Punai & & LC & \\
\hline 37. & Yuhina zantholeuca & Cica keladi & & LC & \\
\hline 38. & Zoothera interpres & Anis kembang & & NT & \\
\hline 39 & Zosterops palpebrosus & Pleci & & LC & \\
\hline
\end{tabular}

Ket: ${ }^{1}$ PP (Peraturan Pemerintah (A, UU No. 5/1990 tentang Konservasi Sumber Daya Alam Hayati dan Ekosistemnya; B, No. P. 106 / MENLHK / SETJEN/KUM.1 / 12 / 2018 tentang Jenis Tumbuhan dan Satwa yang Dilindungi.

${ }^{2}$ IUCN Redlist Database (International Union Conservation of Nature and Natural Resources); ${ }^{3}$ CITES (Convention on International Trade of Endangered Wildlife Flora and Fauna); 
Berdasarkan dari 39 jenis burung yang diperdagangkan di Kabupaten Kubu Raya, 10 jenis burung masuk ke dalam kategori dilindungi menurut Undang-Undang Republik Indonesia, IUCN dan CITES. Diantaranya 4 jenis burung yang dilindungi menurut Undang-Undang No.5 Tahun 1990 Tentang Konservasi Sumber Daya Alam Hayati dan Ekosistemnya, Peraturan Menteri Lingkungan Hidup Dan Kehutanan Republik Indonesia Nomor P.106/MENLHK/SETJEN/KUM.1/12/2 018. Yaitu Cucak hijau (Chloropsis sonnerati), Serindit (Loriculus galgulus), Celilin (Platylophus galericulatus), dan Sikatan (Rhipidura javanica). Bahwa penetapan jenis satwa yang dilindungi dilakukan dengan mempertimbangkan kondisi faktual populasi di alam. Misalnya berdasarkan hasil penelitian jenis Cucak hijau merupakan kategori jenis burung dengan tingkat perdagangan yang rendah yaitu hanya ditemukan 8 individu, Kemungkinan besar hal ini juga disebabkan oleh tekanan terhadap habitatnya, mereka menghuni tajuk pohon berdaun lebat di hutan primer atau sekunder MacKinnon et al (2000). Cucak hijau juga termasuk jenis yang sulit dijumpai, perburuan dan perdagangan menunjukan bahwa distribusi burung ini di alam mengalami penyusutan sangat signifikan. Dalam Burungnesia (2019) Sebaran alami jenis dan jumlah individu dijawa tercatat sebanyak 250-499 individu.

Selanjutnya 1 jenis burung termasuk dalam status perlindungan menurut CITES yang mengelompokkan kategori-kategori jenis dalam Appendix 2 (jenis yang statusnya belum terancam tetapi akan terancam punah apabila dieksplotasi berlebihan) yaitu jenis Serindit (Loriculus galgulus). Dalam penelitian Juhardiansyah et al, (2019) bahwa jenis serindit termasuk kedalam jenis burung yang tingkat perburuan dan perdagangan cukup tinggi, hal ini mengungkapkan kenyataan bahwa jenis ini telah menjadi komoditas ekonomi dengan permintaan pasar yang kuat. Kondisi ini menyebabkan jenis ini semakin sulit ditemukan di alam.

Dalam status keterancaman menurut IUCN terdapat 8 jenis burung diantaranya 3 jenis berstatus: $\mathrm{VU}=$ Vulnerable (terancam) yaitu Cucak hijau (Chloropsis sonnerati), Jalak (Acridotheres javanicus), Putar (Streptopelia dusumieri). dan 5 jenis berstatus NT $=$ Near Threatened (mendekati terancam) jenis burung tersebut yaitu Anis kembang (Zoothera interpres), Celilin (Platylophus galericulatus), Perenjak batu (Malacopteron magnum), Merbak Gunung (Pycnonotus eutilotus) dan Love bird (Agapornis lilianae). Burungburung ini masuk ke dalam jenis dengan kategori terancam dan mendekati terancam. Salah satunya adalah burung jalak, jenis ini termasuk umum lebih mudah dijumpai dan melimpah keberadannya di alam dan berasosiasi dengan kehadiran manusia, biasa ditemukan di tempat-terbuka didaerah persawahan dan hidup bermutualisme dengan hewan ternak besar 
JURNAL HUTAN LESTARI (2019)

Vol. 7 (3) : 1412 - 1423

(sapi\&kerbau) MacKinnon et al (2000). Namun perburuan dan perdagangan yang sangat tinggi membuat populasi liar jenis ini menjadi langka di habitat aslinya. Dalam Burungnesia (2019)

Sebaran alami di Jawa ditemukan 6-9 individu.

Berikut adalah gambar jenis-jenis burung yang dilindungi.

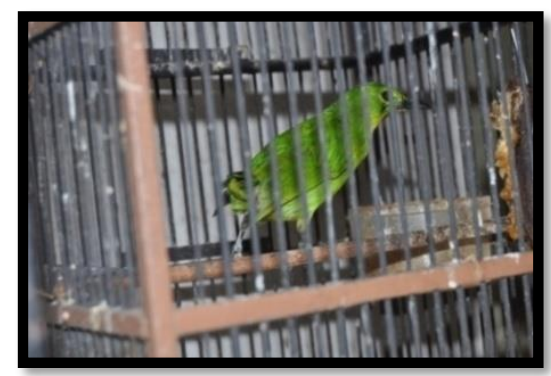

Gambar 3. Cucak Hijau ( Chloropsis sonnerati)

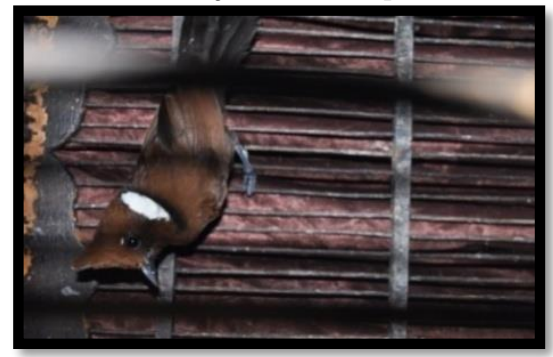

Gambar 5. Celilin (Platylophus galericulatus)

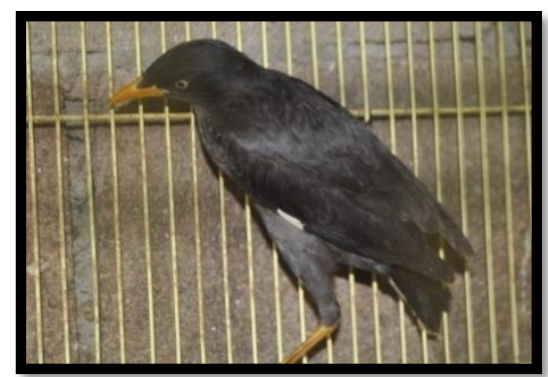

Gambar 7. Jalak (Acridotheres javanicus)

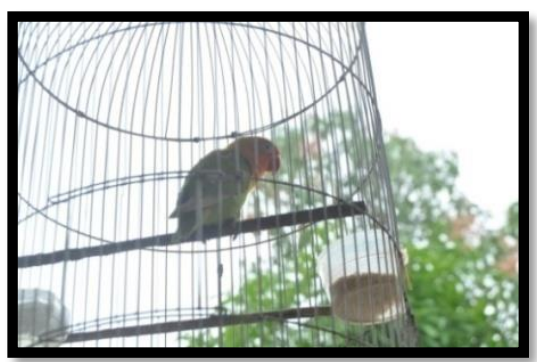

Gambar 9.Love bird (Agapornis lilianae)

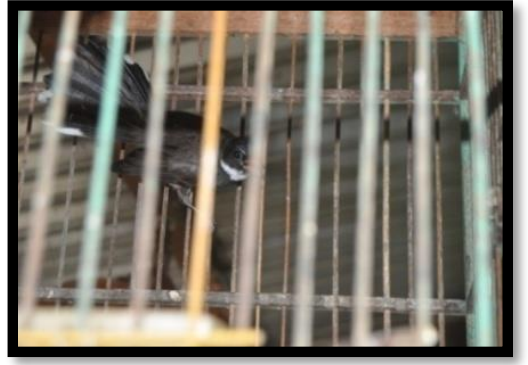

Gambar 4. Sikatan (Rhipidura javanica)

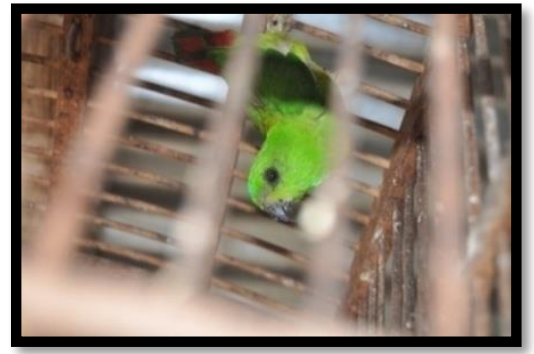

Gambar 6. Serindit (Loriculus galgulus)

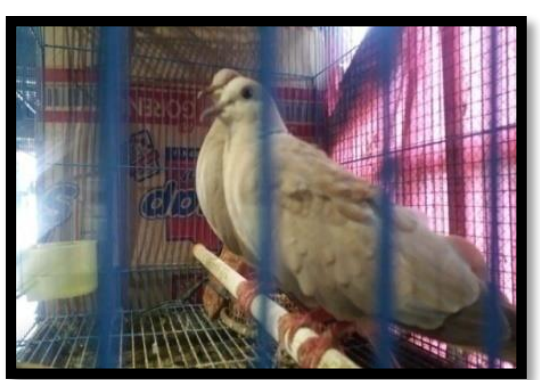

Gambar 8. Putar (Streptopelia dusumieri)

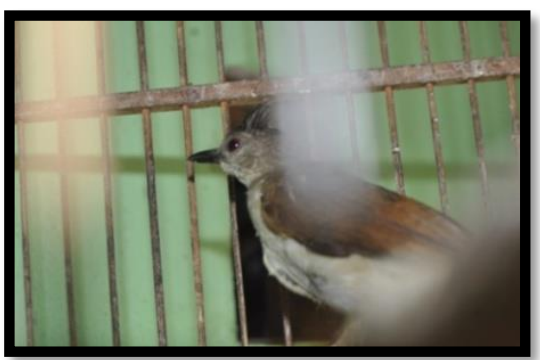

Gambar 10. Merbak gunung (Pycnonotus eutilotus) 


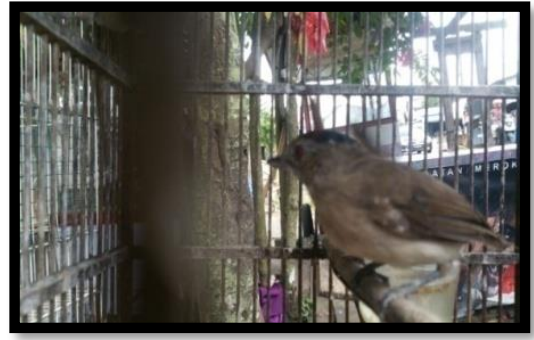

Gambar 11. Perenjak batu (Malacopteron magnum)

\section{Kesimpulan}

Diketahui jenis burung yang diperdagangkan di Kabupaten Kubu Raya sedikitnya 39 jenis burung yang tergolong kedalam 21 suku (famili). Terdapat 10 jenis burung yang dilindungi, diantaranya 4 jenis burung dilindungi menurut Peraturan Menteri Lingkungan Hidup Dan Kehutanan Republik Indonesia Nomor P.106/MENLHK/SETJEN/KUM.1/12/2 018, 1 jenis burung menurut CITES Appendix II dan 8 jenis dikatagori IUCN 3 jenis berstatus VU, dan 5 jenis berstatus NT. Masyarakat belum mengetahui mengenai perlindungan satwa liar terutama jenis burung sehingga masih banyak terjadi perdagangan burung yang dilindungi oleh masyarakat.

\section{Saran}

Diperlukan penelitian burung lanjutan secara rutin untuk melakukan pemantauan burung liar yang diperdagangkan di Kabupaten Kubu Raya maupun lokasi lainnya, sehingga data dan informasi burung-burung yang diperdagangkan dapat diketahui. Perlu adanya sosialisasi terhadap para pelakupelaku yang terlibat dalam kegiatan perdagangan burung agar tidak ada lagi burung yang dilindungi

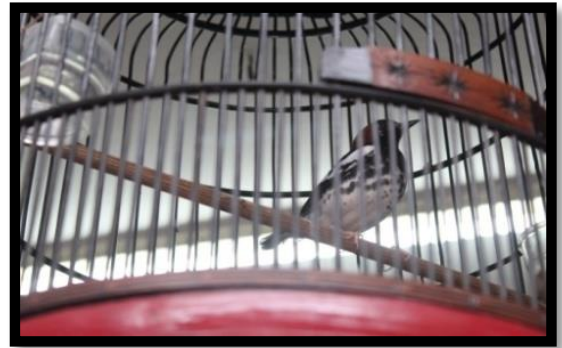

Gambar 12. Anis kembang (Zoothera interpres)

diperdagangkan, hal ini merupakan upaya untuk melestarikan populasi burung liar di alam dengan melakukan upaya peningkatan kesadaran masyarakat, memberikan perhatian untuk menjamin kelestarian satwa liar burung dengan usaha penangkaran, pembatasan perburuan dan perlarangan terhadap burung yang populasinya sedang kritis atau terancam jumlahnya.

\section{Daftar Pustaka}

Bernad, H. 2002. Research Methods in Antropology: Qualitative and Quantitative Methods, Third edition, Altamitra Press, Walnut Creek, California.

Burungnesia. 2019. Daftar Pustaka Seri Infografis Tahunan

Haryoko, T. 2010. Komposisi Dan Jumlah Burung Liar Yang Diperdagangkan Di Jawa Barat. Bidang Zoologi, Pusat Penelitian Biologi-LIPT.

Iskandar, J. 2015. Keanekaragaman Hayati Binatang dan Manfaat Ekologi Bagi Manusia. Yogyakarta : Graha Ilmu.

Juhardiansyah, Erianto, Idham M. 2019. Studi Jenis Burung Yang Diperdagangkan di Kota Ketapang. Jurnal Hutan Lestari.7(1) : 237-247. 
MacKinnon, J., Karen, P.,dan Balen, B.V. 2010. Seri Panduan Lapangan Burung-burung di Sumatera, Jawa, Bali, dan Kalimantan. Bogor: Pusat Penelitian dan Pengembangan Biologi LIPI.

Metz S. 2005. The Current status of Indonesia cockatoos in the wild: Returning smuggled parrots to their forest homes. Parrot Society of Australia 15, 34-37.

Nazir, Moh. 1998 Problematika Penulisan Cerita Rakyat. Jakarta. Balai Pustaka.

Nurdin, Nasihin. I, Guntara. A. Y. 2017. Pemanfaatan Keanekaragaman Jenis Burung Berkicau Dan Upaya Konservasi Pada Kontes Burung Berkicau Di Kabupaten Kuningan Jawa Barat. Program Studi Kehutanan, Fakultas Kehutanan Universitas Kuningan. Wanaraksa Vol. 11.

Peraturan Menteri Lingkungan Hidup Dan Kehutanan Republik Indonesia Nomor P.106/MENLHK/SETJEN/KUM. 1/12/2018 Tentang Perubahan Kedua Atas Peraturan Menteri Lingkungan Hidup Dan Kehutanan Nomor P.20/MENLHK/SETJEN/KUM.1/ 6/2018 Tentang Jenis Tumbuhan Dan Satwa Yang Dilindungi.

ProFauna, 2009. ProFauna 's Report: Wildlife Trade Survey on the Bird Market in Java. ProFauna Indonesia, http://www.profauna.org.

Saifuddin. 2013. Identifikasi Dan Inventarisasi Jenis Burung Berstatus Dilindungi Di Pasar Hewan. Yogyakarta.
Sawitri, R., R. Garsetiasih, A.S. Mukhtar. (2010). Konservasi insitu dan eks-situ burung punai (Columbidae) sebagai sumber pangan. Laporan Proyek Program Insentif Ristek. 30 hal. Puslitbang Hutan dan Konser-vasi Alam, Bogor.

UU No. 5/1990 Tentang Konservasi Sumber Daya Alam Hayati dan Ekosistemnya. Jakarta. 